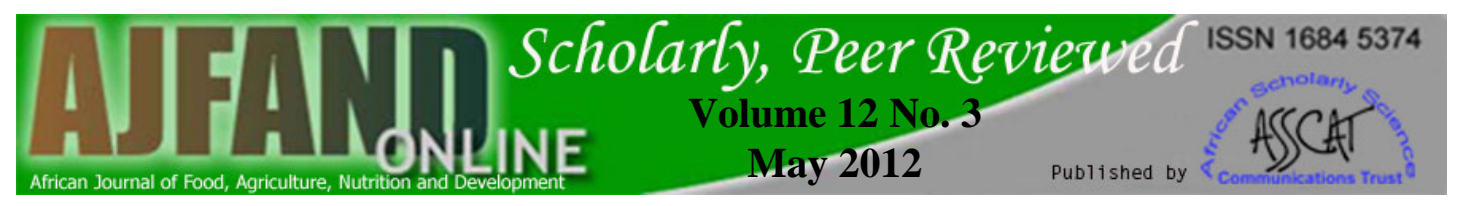

\title{
EFFECT OF DIFFERENT NITROGEN FERTILIZER RATES ON YIELD AND YIELD RELATED TRAITS FOR SEVEN DURUM WHEAT (Triticum turgidum L. var Durum) CULTIVARS GROWN AT SINANA, SOUTH EASTERN ETHIOPIA
}

\author{
Woyema $A^{1}$, Bultosa $G^{* 2}$ and $A$ Taa $^{3}$
}

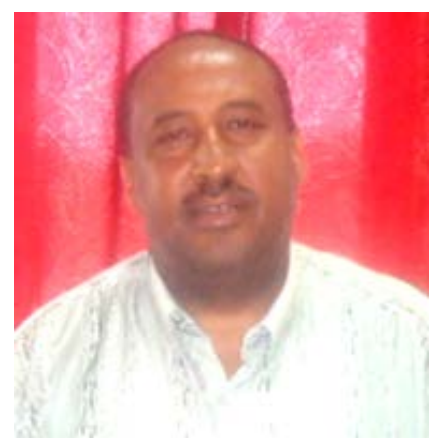

Geremew Bultosa

*Corresponding author email: Bultosageremew@yahoo.com

${ }^{1}$ Sinana Agricultural Research Center, Box 238, Bale Robe, Ethiopia

${ }^{2}$ Department of Food Science and Postharvest Technology, Haramaya University,Box 138, Dire Dawa, Ethiopia

${ }^{3}$ Oromiya Agricultural Research Institute, P O. Box 81265, Finfinne, Ethiopia 


\section{ABSTRACT}

An experiment was conducted at Sinana district on farmers field to study the effects of different nitrogen fertilizer rates $\left(0=\right.$ control, 23, 46 and $\left.69 \mathrm{~kg} \mathrm{ha}^{-1}\right)$ on crop phenology, yield and yield related traits, nitrogen uptake parameters and grain protein content of seven durum wheat cultivars (Ude, CDSS93Y107, Ejersa, Bekelcha, CD94523, Cocorit71 and Inglize). The experimental site soil samples were analyzed and texture was clay, with organic matter of $4.5 \%$, available P of $8.8 \mathrm{ppm}$, CEC of 27 $\mathrm{cmol} \mathrm{kg}^{-1}$ and $\mathrm{pH}$ of 7.1 and total nitrogen content of $0.24 \%$. The experiment was conducted in a Randomized Complete Block Design (RCBD) with three replications. The result showed that nitrogen rates and cultivars had significant effect on yield, yield related traits, nitrogen uptake parameters and protein content. The cultivars CD94523 (4989 kg ha ${ }^{-1}$ ), CDSS93Y107 (4923 kg ha-1) and Bekelcha (4605 kg ha-1) showed better grain yield performance at the highest rate of nitrogen (69 kg ha-1) application probably due to highest response of the cultivars and use efficiency to $\mathrm{N}$ fertilizer. At $46 \mathrm{~kg} \mathrm{ha}^{-1} \mathrm{~N}$ rate application, cultivars (Ude, Ejersa, Cocorit 71 and Inglize) showed also high grain yield similar to grain yield of $69 \mathrm{~kg} \mathrm{ha}^{-1} \mathrm{~N}$ application. The TKW and HLW of the cultivars were ranged 42.5-49.5 $\mathrm{g}$ and 78.5$81.6 \mathrm{~kg} \mathrm{hL}^{-1}$, respectively. Among cultivars, Ude and Bekelcha were superior for TKW. The HLW of Ude, CDSS93Y107, Ejersa and Bekelcha were significantly superior. Increased $\mathrm{N}$ rates up to $69 \mathrm{~kg} \mathrm{ha}^{-1}$ had increased straw $\mathrm{N}$ uptake, grain $\mathrm{N}$ uptake and total $\mathrm{N}$ uptake and the lowest $\mathrm{N}$ uptake was for the control treatment. The grain protein content $(12.5 \%, \mathrm{mb})$ had ranged from 10.2\% (Inglize) to $13.4 \%$ (Ude, Ejersa and Bekelcha) $(\mathrm{P}>0.05)$. The highest $\mathrm{N}$ rates resulted in $15 \%$ more grain protein content than the control treatment which is essential for pasta processing and better nutritional value.

Key words: Durum wheat, Yield, Protein, Nitrogen 


\section{INTRODUCTION}

Ethiopia is major producer of wheat in East Africa (> 700,000 ha), accounting for over $70 \%$ of total wheat area in the region [1]. The most important wheat growing areas are located in the highlands (i.e., > 2000 m.a.s.l.) characterized by a mean annual rainfall $>1000 \mathrm{~mm}$, mean annual temperatures between 16 and $20^{\circ} \mathrm{C}$ [1] of wide range of soil condition in Ethiopia [2]. The temperature, rainfall and altitude hospitable to wheat production are located in the south- eastern highlands of Ethiopia that shares $75 \%$ of the total wheat production area of Ethiopia [1].

In recent years, wheat became one of the most important cereal crops in Ethiopia ranking $3^{\text {rd }}$ in total grain production (17.02\%) next to tef [3]. Durum wheat (Triticum turgidum L. var Durum) is the second most cultivated wheat species in the world, next to common wheat [4]. In Ethiopia, durum wheat grain is most important for industrial pasta and macaroni productions [5]. Durum wheat grain is also consumed traditionally in Ethiopia in the form of whole wheat, fermented and leavened local bread.

Globally, nitrogen is considered as the second most limiting factor in the crop production and limits yield in non-fertilized agriculture [6, 7]. It is applied in order to increase yield and improve crop quality. Nitrogen fertilization contributes significantly to protein content, especially when fertilizer rates satisfy the requirements of both yield and protein formation. Suitable durum wheat grain features for pasta and macaroni products are amber (yellow) color, vitreous endosperm, hardest grain texture and unique combination of grain protein that favors good pasta cooking quality [8]. Durum wheat grain protein functionality can be influenced by $\mathrm{N}$ fertilization, particularly in the varieties of relatively with less gluten strength [9]. Information on the quality characteristics of some Ethiopian wheat varieties with respect to flour protein content, flour yield, hectoliter weight, thousand kernel weight and grain yield, revealed a significant effect of fertilizer (i.e., linear increase trends for grain and flour yields whereas for flour protein content, hectoliter weight and thousand kernels weight a linear increase trend to some levels of fertilizer applied and then a decreasing trend) [10]. In studies conducted on five durum wheat varieties grown in Ethiopia at Debre Zeit location, gluten contents were influenced by both varieties and nitrogen levels and in another location (Akaki) significant effect were only observed among the varieties [32].

Choice of genotype and $\mathrm{N}$ fertilization is one of the recognized cultivation techniques that have large influence on grain yield and quality in wheat grain production [7, 11]. Currently, there is a high demand by both commercial and small-scale farmers for durum wheat with high grain yield and better end-use quality to meet the increasing demand of durum wheat grain processors in Ethiopia. However, there is limited information on the impact of $\mathrm{N}$ application rate on yield and quality aspect of durum wheat cultivars cultivated in Ethiopia [12, 32], hence farmers use blanket recommendation of $100 \mathrm{~kg}$ DAP and $50 \mathrm{~kg}$ urea per hectare. Information on yield and yield related traits under different nitrogen rates for most of the recently released and advanced durum wheat lines in Ethiopia are limited. Therefore, in this work the effects of nitrogen application rates $\left(0,23,46\right.$ and $\left.69 \mathrm{~kg} \mathrm{~N} \mathrm{ha}^{-1}\right)$ on crop phenology, 
grain yield, yield related traits, nitrogen uptake parameters and grain protein content for seven durum wheat cultivars grown at Sinana, Bale, south eastern Ethiopia were reported.

\section{MATERIALS AND METHODS}

\section{Experimental site}

Field experiment was conducted at Sinana district on farmers' field near Sinana Agricultural Research Center (SARC) during the 2008/09 main cropping season. The location has an altitude of 2400 masl in Oromia Regional State $\left(7^{0} \mathrm{~N}\right.$ latitude and $40^{\circ}$ E longitudes). Total annual rain precipitation on growing season was $669.1 \mathrm{~mm}$ and was $677.1 \mathrm{~mm}$ (mean) for the long-term. The monthly mean maximum and minimum air temperatures on growing season were $19.5{ }^{\circ} \mathrm{C}$ and $9.6{ }^{\circ} \mathrm{C}$, and for the long term (mean) was $21.1^{\circ} \mathrm{C}$ and $9.4^{0} \mathrm{C}$, respectively. The dominant soil type is pellic Vertisol and slightly acidic ( $\mathrm{pH}=6)$.

\section{Trial design}

The experiment was designed as factorial in randomized complete block design with three replications comprising four nitrogen treatments (control/no nitrogen applied, 23, 46 and $69 \mathrm{~kg} \mathrm{~N} \mathrm{ha}^{-1}$ ) and seven durum wheat cultivars (Table 1). The nitrogen levels were selected in part by considering the national research blanket recommendation of $46 \mathrm{~kg} \mathrm{~N} / \mathrm{ha}$ for wheat and on the other hand the farmers practice of below and above the recommendation. The cultivars were selected based on their agronomic performance, difference in yield and morphological characteristics. Each plot had 7 rows, $3 \mathrm{~m}$ in length and $20 \mathrm{~cm}$ between rows. View of the trial field both at vegetative and near physiological maturity were shown in Figures 1 and 2.

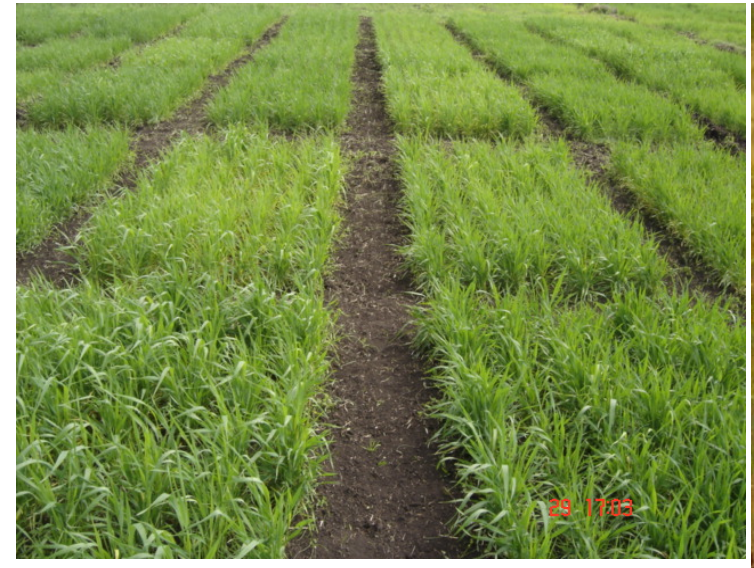

Figure 1: Durum wheat trial field at vegetative stage



Figure 2: Durum wheat trial field near the physiological maturity

\section{Soil sampling and analysis}

Soil samples were taken at a depth of $0-30 \mathrm{~cm}$ at planting and after harvesting and analyzed at the Soil Science Laboratory of SARC. Organic matter content was determined by oxidation of organic carbon with acid potassium di-chromate $\left(\mathrm{K}_{2} \mathrm{Cr}_{2} \mathrm{O}_{7}\right)$ by the Walkley and Black method [13]. Total nitrogen was analyzed by 
Micro-Kjeldhal method [14]. Soil pH was determined in 1:2.5 (weight/ volume) soil to water dilution ratio [15]. Cation exchange capacity was measured after saturating the soil with $1 \mathrm{~N}$ ammonium acetate $\left(\mathrm{NH}_{4} \mathrm{OAC}\right)$ and displacing it with $1 \mathrm{~N}$ NaOAC [16]. Available phosphorus was determined using Olsen method [17]. Soil texture was clay, with organic matter of $4.5 \%$, available P of $8.8 \mathrm{ppm}$, CEC of $27 \mathrm{cmol} \mathrm{kg}^{-1}$ and $\mathrm{pH}$ of 7.1. Total nitrogen content of the experimental soil was $0.24 \%$.

Planting was done on 20 August 2008 at a seeding rate of $150 \mathrm{~kg} \mathrm{ha}^{-1}$. At planting $19.32 \mathrm{~g} /$ plot triple super phosphate $\left(46 \% \mathrm{P}_{2} \mathrm{O}_{5}\right)$ was applied to each plot. Both at planting and after full tillering stage $1 / 2$ dose of $\mathrm{N}$ was applied as urea.

Crop growth stage was assessed based on the decimalized key developed [31]. Plant height $(\mathrm{cm})$ was measured at maturity as the height from ground level to the tip of spike excluding awns. Spike length $(\mathrm{cm})$ was obtained by measuring 10 random spikes per plot from the base of spike up to apex of the terminal spikelet excluding awns. Grain was harvested at physiological maturity (at 138 days after planting) manually using sickle from the central five rows. Harvest index was calculated as the percentage ratio of grain yield to the total above ground biomass yield multiplied by 100. Biomass yield $\left(\mathrm{kg} \mathrm{ha}^{-1}\right.$ ) was obtained by weighing above ground dry matter of plant (straw and grain) in each plot. Grain yield $\left(\mathrm{kg} \mathrm{ha}^{-1}\right)$ was determined from the central five rows harvested and data was given on $12.5 \%$ moisture basis (mb). Straw yield $\left(\mathrm{kg} \mathrm{ha}^{-1}\right.$ ) was obtained by the difference between biomass yield and grain yield. Thousand kernel weight $(T K W)$ and hectoliter weight (HLW) were measured on dockage free samples [18].

\section{Grain $\mathbf{N}$ and straw $\mathbf{N}$ uptakes}

At physiological maturity (for eaxample, 138 days after planting) five randomly selected $0.5 \mathrm{~m}$ length samples per net plot were harvested at ground level from all the central five rows and partitioned into grain and straw and were oven dried at $70{ }^{\circ} \mathrm{C}$ for over 24 hrs [19]. After drying, straw was ground with rotor mill to pass $2 \mathrm{~mm}$ sieve and for grain $0.5 \mathrm{~mm}$ sieve. Nitrogen content was determined by taking about $0.25 \mathrm{~g}$ grain flour and $0.50 \mathrm{~g}$ for straw by micro-Kjeldahl method [18].

Grain nitrogen $\left(\mathrm{kg} \mathrm{ha}^{-1}\right)$ uptake was computed as grain yield multiplied by percent $\mathrm{N}$ content of the grain for each plot. Straw nitrogen $\left(\mathrm{kg} \mathrm{ha}^{-1}\right)$ uptake was calculated as straw yield multiplied by percent $\mathrm{N}$ content of the straw in each plot. Total nitrogen $\left(\mathrm{kg} \mathrm{ha}^{-1}\right)$ uptake was obtained as the sum of grain nitrogen uptake and straw nitrogen uptake. Grain protein content was determined by micro-Kjeldahl method [18]. Protein $(\%)=\mathrm{N} \% \times 5.75$.

\section{Data analysis}

All data collected were subjected to analysis of variance (ANOVA) using SAS GLM procedure [20]. Fisher's Least Significant Difference Tests (LSD) was used for means separation when the F-test indicated significant differences for cultivars and nitrogen rates. 


\section{RESULTS}

The effect of nitrogen fertilization rates and cultivars on durum wheat crop phenology, yield related traits, nitrogen uptake parameters, TKW, HLW and GPC are given in Tables 2 and 3. The number of days required to anthesis (DAS) i.e when anther extrudes from the central spikletes of the spike, had varied between 81 and 86 days. Advanced line CDSS93Y107 took longer DAS than the improved durum wheat cultivars while Cocorit71 took shortest DAS followed by Bekelcha and line CD94523. The number of days required to maturing (DPM) had varied between 134 and 143 days. Maximum plant height was observed among $\mathrm{N}$ rate of $69 \mathrm{~kg} \mathrm{ha}^{-1}(89.4$ $\mathrm{cm})$ and $46 \mathrm{~kg} \mathrm{ha}^{-1}(88.2 \mathrm{~cm})$ and minimum $(84.5 \mathrm{~cm})$ was observed in the control. The lowest mean spike length was recorded for control treatment and no significant variation was observed in the spike length for different nitrogen rate applications. The cultivars mean spike length were ranged $5.8 \mathrm{~cm}$ (Ude) and $6.3 \mathrm{~cm}$ (CD94523) (Table 2) and the highest was obtained from CDSS93Y107 and CD94523.



Figure 3: Percentage of nitrogen content in wheat grain and straw at different $\mathbf{N}$ rates

The lowest grain yield was among Ude, CDSS93Y107, Ejersa and Cocorit 71 at their control treatment. The highest grain yield was among CDSS93Y107, Bekelcha and CD94523 at the highest nitrogen treatment (69 $\mathrm{kg} \mathrm{N} \mathrm{ha}^{-1}$ ) (Table 4). For UDe, CDSS93Y107 and Ejersa cultivars no significant grain yield difference ( $>0.05)$ were observed between $46 \mathrm{~kg} \mathrm{~N} \mathrm{ha}^{-1}$ and $69 \mathrm{~kg} \mathrm{~N} \mathrm{ha}^{-1}$ applications. But in general for most cultivars an increase in nitrogen application rate had resulted in an increase of grain yield.

The N Fertilizer rates, averaged over cultivars, gave higher biomass yield than control treatment (Table 2). Among the cultivars, the highest biomass yield (14945 kg ha ${ }^{-1}$ ) was for Inglize and no significant difference $(\mathrm{p}>0.05)$ was observed among the rest. Compared to control, biomass mean yield was increased by $21.5 \%, 44.3 \%$ and $60.6 \%$ for 23, 46 and $69 \mathrm{~kg} \mathrm{~N} \mathrm{ha}^{-1}$ treatments, respectively. Nitrogen treatments had reduced harvest index (HI) significantly $(\mathrm{p}<0.05)$ as compared to the control. Reduction in HI 
relative to the control was $5.9 \%, 12.5 \%$ and $12.5 \%$ for 23,46 and $69 \mathrm{~kg} \mathrm{~N} \mathrm{ha}^{-1}$ treatments, respectively. Averaged over varieties, highest straw yield was for the highest $\mathrm{N}$ rate with yield increase of $68.9 \%$ over the control treatment and $35.5 \%$ over the $23 \mathrm{~kg} \mathrm{~N} \mathrm{ha}^{-1}$. The highest mean straw yield $\left(11325 \mathrm{~kg} \mathrm{ha}^{-1}\right)$ was obtained by local cultivar Inglize which was significantly different from the rest. No significant difference ( $p>0.05$ ) for straw yield was observed among the rest.

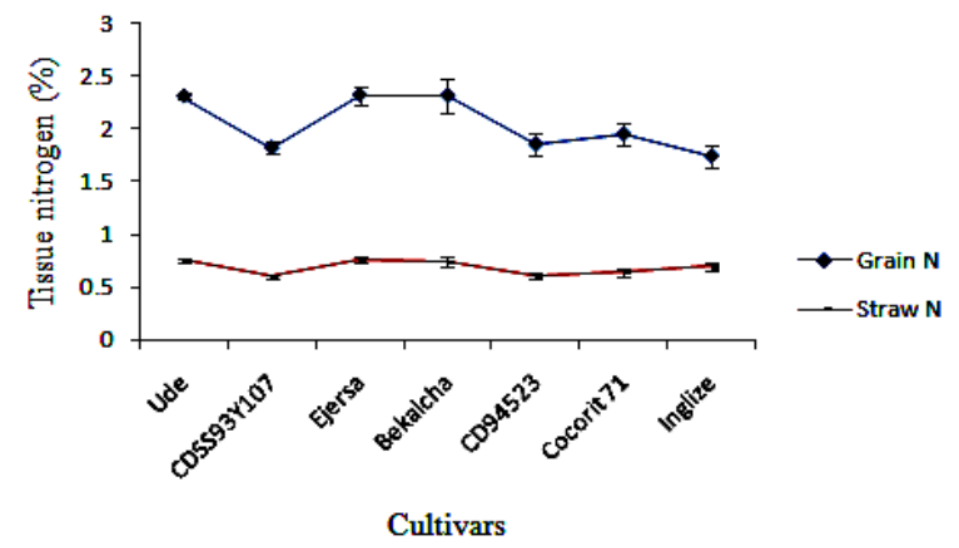

Figure 4: Percentage of nitrogen content in wheat grain and straw for different durum wheat cultivars

Application of $69 \mathrm{~kg} \mathrm{~N}^{-1}$ resulted into significantly $(\mathrm{P}<0.001)$ higher grain $\mathrm{N}$ content, and gave 14.9\% higher $\mathrm{N}$ content than control treatment and $15.5 \%$ than 23 $\mathrm{kg} \mathrm{N}^{-1}$ (Figure 3). The cultivars Ude, Ejersa and Bekelcha were statistically at par and had 32\% higher grain N content than Inglize (Figure 4). Similarly, cultivars Ude and Ejersa followed by Bekelcha had higher straw $\mathrm{N}$ content than others. Increased $\mathrm{N}$ rates up to $69 \mathrm{~kg} \mathrm{ha}^{-1}$ had increased straw $\mathrm{N}$ uptake (SNU), grain $\mathrm{N}$ uptake (GNU) and total $\mathrm{N}$ uptake (TNU) and the lowest uptake was for the control treatment (Table 3). Application of $23 \mathrm{~kg} \mathrm{~N} \mathrm{ha}^{-1}$ and $69 \mathrm{~kg} \mathrm{~N} \mathrm{ha}^{-1}$ gave $15.5 \%$ and $67.0 \%$ more GNU than the control treatment, respectively. The highest GNU was for Bekelcha and the lowest was for Inglize. The highest (168 kg ha ${ }^{-1}$ ) and the lowest (95 kg ha-1) TNU values were obtained from the application of $69 \mathrm{~kg} \mathrm{~N} \mathrm{ha}^{-1}$ and control treatments, respectively. Among the cultivars, Bekelcha, Inglize and Ude were resulted into highest TNU as compared to the rest cultivars. The lowest TNU was observed in Cocorit71.

The maximum TKW (g) was observed among 23, 46 and $69 \mathrm{~kg} \mathrm{~N}^{-1}$ rates $(\mathrm{P}>0.05)$ (Table 3). Minimum TKW was for the control treatment. Among the cultivars, Ude and Bekelcha were superior for TKW. No significant difference $(P>0.05)$ in HLW was observed due to different $\mathrm{N}$ rates (Table 3). The highest HLW was obtained among the cultivars: CDSS93Y107 $\left(81.6 \mathrm{~kg} \mathrm{hl}^{-1}\right)$ followed by Ejersa $\left(81.3 \mathrm{~kg} \mathrm{hl}^{-1}\right)$, Bekelcha $\left(81.1 \mathrm{~kg} \mathrm{hl}^{-1}\right)$ and Ude $\left(80.7 \mathrm{~kg} \mathrm{hl}^{-1}\right)(\mathrm{P}>0.05)$. The highest grain protein content (GPC) (13\%) was recorded for the highest $\mathrm{N}$ rates (Table 3). The cultivars grain protein contents had ranged 10.2\% (Inglize) to 13.4\% (Ude, Ejersa and Bekelcha) $(\mathrm{p}<0.05)$. 


\section{DISCUSSION}

In the study among $\mathrm{N}$ rates no significant variations $(\mathrm{P}>0.05)$ for both DAS and DPM were observed. Landrace cultivar Inglize took longer DPM (generally by 6 to 9 days) as compared to the improved cultivars which probably shows breeders have managed to reduce maturity time by selecting early cultivars in order to match the crop developmental stages with seasonal rainfall patterns. Mean values for nitrogen rates showed, plant height had increased with each increment of nitrogen rates from control to the highest rate but no significant difference $(p>0.05)$ was observed between the two higher $\mathrm{N}$ rates. This increase was probably due to availability of more nutrients, which helped in the maximum vegetative growth of the durum wheat plant and similar results of plant height increases with $\mathrm{N}$ rates increases were also reported elsewhere $[6,21]$.

The interactions between cultivars and nitrogen rates were significant $(\mathrm{P}<0.05)$ for grain yield indicating grain yield was influenced by $\mathrm{N}$ application rate differences. The cultivars CD94523, CDSS93Y107 and Bekelcha showed better grain yield performance at the highest rate of nitrogen $\left(69 \mathrm{~kg} \mathrm{ha}^{-1}\right)$ probably due to the highest response by these cultivars to $\mathrm{N}$ and use efficiency. Cultivar CD94523 also showed better performance on grain yield at the control treatment than other cultivars. On the other hand, Ejersa and Ude showed lowest grain yield performance under the control treatment. Probably, this was due to genetic potential variation of the cultivars. The large grain yield variation among durum wheat under different nitrogen treatments could help in the selection of better cultivars for different $\mathrm{N}$ supply environments and similar results of cultivars variations in durum wheat grain yield on nitrogen applications were also reported [6, 22]. Biomass yield had increased with $\mathrm{N}$ rate increase from control to the highest level and similar result also reported elsewhere [23]. The HI was ranged between 33-36\% except for Inglize and no significant difference ( $>0.05)$ was observed among all improved and advanced lines that suggests there is nearly an equal early assimilation and utilization of nitrogen nutrients by these cultivars. The $\mathrm{N}$ rate significantly enhanced straw yield since $\mathrm{N}$ usually promotes the vegetative growth of the plant [24]. The relatively high above ground dry matter production in late maturing cultivar Inglize implies that this cultivar may be preferable for integrated crop-livestock production systems where farmer has multiple uses for durum wheat. Highest fertilizer $\mathrm{N}$ rate had produced maximum grain $\mathrm{N}$ while the lowest $\mathrm{N}$ rate gave minimum grain $\mathrm{N}$ content, implying a positive response to $\mathrm{N}$ fertilizer by the cultivars and similar finding also reported elsewhere [25]. Increase in grain $\mathrm{N}$ uptake by wheat also depends on the cultivars potentials to absorb $\mathrm{N}$ more efficiently from the soil [26]. Mean straw $\mathrm{N}$ uptake from control to the highest $\mathrm{N}$ rate had ranged between 37 and $71 \mathrm{~kg} \mathrm{~N} \mathrm{ha}^{-1}$. The cultivar Inglize had higher SNU than the rest and perhaps due to its longer date of maturity, there could be translocation of more nutrients in to vegetative part of the plant.

The high TKW with high $\mathrm{N}$ rate application might be attributed to a better nutritional status of the plants, which resulted in good grain filling and development and such a positive linear response of TKW to $\mathrm{N}$ rate has been reported $[6,24]$ and in some up to $100 \mathrm{~kg} \mathrm{ha}^{-1} \mathrm{~N}$ application [27]. Contrary to grain yield responses, TKW was 
significantly smaller in higher-yielding cultivars CD94523 than low yielder Ude (Tables 2 and 3). Variations in HLW due to different nitrogen rate applications were insignificant. The HLW of Ude, CDSS93Y107, Ejersa and Bekelcha cultivars appeared superior $\left(\geq 81 \mathrm{~kg} \mathrm{hl}^{-1}\right.$ ) and meet the demand of most semolina miller standards [28]. The highest $\mathrm{N}$ rate had resulted in 15\% more GPC than the control treatment and in other work an increase of GPC by 20.29\% was reported [29]. This variation in grain protein content of the cultivars may be attributed to their variation in nutrient uptake and translocation capacities to the sink. In general, GPC values found in this work are in the range of GPC $10.2 \%$ to $15.4 \%$ reported for an improved durum wheat cultivars released in Ethiopia between 1966 and 1996 [30].

\section{CONCLUSIONS}

The result suggest that application of $69 \mathrm{~kg} \mathrm{~N} \mathrm{ha}^{-1}$ seems reached economical with high grain yield production for CD94523, CDSS93Y107 and Bekelcha. For cultivars Ude, CDSS93Y107 and Ejersa application of $46 \mathrm{~kg} \mathrm{~N} \mathrm{ha}^{-1}$ seems also adequate when one wants to minimize inorganic fertilizer input with modest compatible high grain yield. The high nitrogen rates the more grain protein content, whereas the increase in TKW had occurred only up to certain nitrogen fertilization levels. Cultivars Ude, Ejersa and Bekelcha had the highest grain protein content, which is essential for pasta processing and better nutritional value.

\section{ACKNOWLEDGEMENTS}

This work is part of the M.Sc. thesis and thanks goes to the Oromia Agricultural Research Institute (OARI) for financial sponsorship, Sinana Agricultural Research Center (SARC) and Haramaya University for facilities support and study permit to the $1^{\text {st }}$ author. 


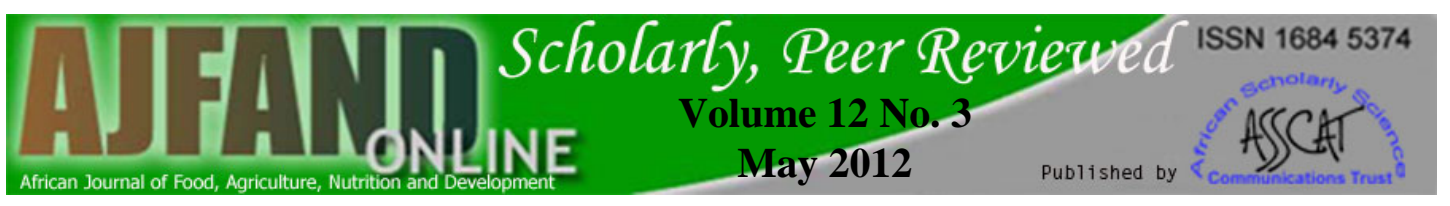

Table 1: Pedigree, origin, releasing center and release year of cultivars used in the experiment

\begin{tabular}{lllll}
\hline Cultivars & Origin & Breeding pedigree & $\begin{array}{l}\text { Releasing } \\
\text { center }\end{array}$ & Year of release \\
& & & DZARC & 2002 \\
Ude & CIMMYT/Ethiopia & CHEN/ALTAR84//JO 69 & SARC & Not released \\
CDSS93Y1 & CIMMYT/Ethiopia & CDSS93Y107 & & \\
Ejersa & CIMMYT/Ethiopia & LABUD/NIGRIS3//Gan & SARC & 2005 \\
& & CD98206 & & \\
Bakelcha & CIMMYT/Ethiopia & 98 OSN Gedilfa/Guerou & SARC & 2006 \\
CD94523 & CIMMYT/Ethiopia & CD94523 & SARC & Not released \\
Cocorit 71 & CIMMYT/Ethiopia & - & DZARC & 1976 \\
Inglize & Ethiopia & Local landrace & - & Landrace \\
\hline
\end{tabular}




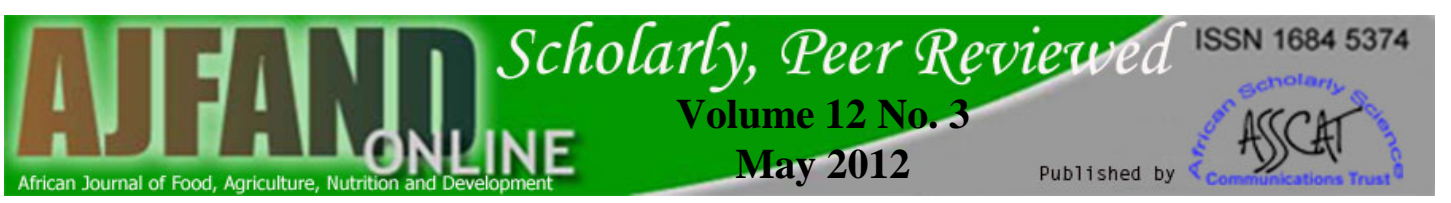

Table 2: The effects of nitrogen fertilization rates and cultivars on crop phenology and yield related traits of seven durum wheat

\begin{tabular}{|c|c|c|c|c|c|c|c|}
\hline $\mathrm{N}$ rates $\left(\mathrm{kg} \mathrm{ha}^{-1}\right)$ & DAS & DPM & Pht & SL & $B M$ & $\mathrm{HI}$ & SY \\
\hline 0 & 82.7 & 136 & $84.5 \mathrm{c}$ & $5.9 \mathrm{~b}$ & 8635d & $36 a$ & $5646 d$ \\
\hline 23 & 83.1 & 136 & $86 \mathrm{~b}$ & $6.1 a$ & $10492 c$ & $34 b$ & $7039 c$ \\
\hline 46 & 82.7 & 137 & $88.2 a$ & $6.2 a$ & $12457 \mathrm{~b}$ & $32 c$ & $8609 \mathrm{~b}$ \\
\hline 69 & 83.1 & 137 & $89.4 a$ & $6.2 a$ & 1387la & $32 c$ & $9540 a$ \\
\hline Mean & 82.9 & 136.5 & 87.0 & 6.1 & 11363.8 & 33.5 & 7708.5 \\
\hline $\operatorname{LSD}(\mathrm{P} \leq .05)$ & NS & NS & 1.4 & 0.12 & 1046 & 0.02 & 895 \\
\hline \multicolumn{8}{|l|}{ Cultivars } \\
\hline Ude & $83.6 \mathrm{~b}$ & $137 b$ & $83.8 \mathrm{~b}$ & $5.8 \mathrm{e}$ & $10583 \mathrm{~b}$ & $33 a$ & $7095 \mathrm{~b}$ \\
\hline CDSS93Y107 & $86.1 a$ & $136 \mathrm{bc}$ & 81.led & $6.3 a$ & $11161 \mathrm{~b}$ & $34 a$ & $7380 \mathrm{~b}$ \\
\hline Ejersa & 83. Ibc & $137 b$ & $81.2 \mathrm{~cd}$ & $6.28 \mathrm{bc}$ & $10109 \mathrm{~b}$ & $36 a$ & $6650 \mathrm{~b}$ \\
\hline Bekelcha & $81.9 \mathrm{de}$ & $134 c$ & $81.7 \mathrm{c}$ & $6.0 \mathrm{~d}$ & $11194 \mathrm{~b}$ & $34 a$ & $7467 \mathrm{~b}$ \\
\hline CD94523 & 82cde & $134 c$ & $84.9 \mathrm{~b}$ & $6.3 a$ & $11417 \mathrm{~b}$ & $36 a$ & $7431 \mathrm{~b}$ \\
\hline Cocorit 71 & $81.0 \mathrm{e}$ & $136 \mathrm{bc}$ & $79.6 \mathrm{~d}$ & $5.9 \mathrm{de}$ & $10139 \mathrm{~b}$ & $36 a$ & $6616 \mathrm{~b}$ \\
\hline Inglize & $82.4 \mathrm{~cd}$ & $143 a$ & $116.9 a$ & 6.1cd & $14945 a$ & $25 b$ & $11325 a$ \\
\hline Mean & 82.9 & 136.7 & 87.0 & 6.1 & 11364 & 33.4 & 7709.1 \\
\hline $\operatorname{LSD}(\mathrm{P} \leq .05)$ & 1.1 & 2.7 & 1.8 & 0.15 & 1383 & 0.03 & 1183 \\
\hline CV (\%) & 2.4 & 2.4 & 5.2 & 3.1 & 14.9 & 9.8 & 18.7 \\
\hline
\end{tabular}

Means followed by the same letter in a column and row are not significantly different at 5\% level of significance, DAS= days to anthesis,

$\mathrm{DPM}=$ days to physiological maturity, $\mathrm{Pht}=$ plant height, $\mathrm{SL}=$ spike length, $\mathrm{BM}=$ biomass yield, $\mathrm{HI}=$ harvest index, $\mathrm{SY}=$ straw yield 


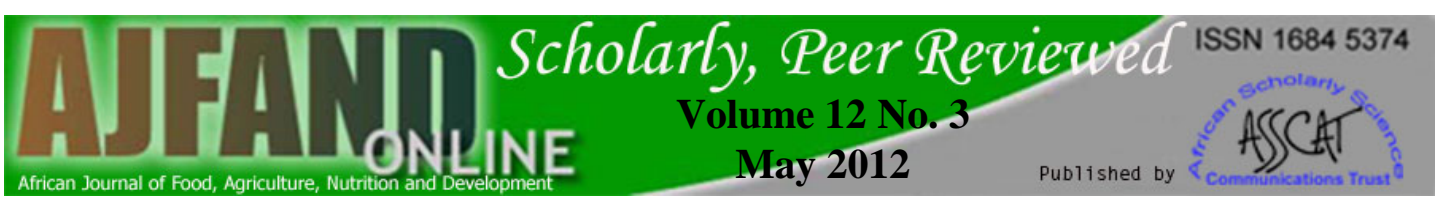

Table 3: The effects of nitrogen fertilization rates and cultivars on nitrogen uptake and some quality (TKW, HLW and GPC) parameters of seven durum wheat

\begin{tabular}{lllllll}
\hline N rates $\left(\mathrm{kg} \mathrm{ha}^{-1}\right)$ & GNU & SNU & TNU & TKW & HLW & GPC \\
\hline 0 & $58 \mathrm{~d}$ & $37 \mathrm{~d}$ & $95 \mathrm{~d}$ & $44.5 \mathrm{~b}$ & 79.8 & $11.3 \mathrm{~b}$ \\
23 & $67 \mathrm{c}$ & $46 \mathrm{c}$ & $113 \mathrm{c}$ & $45.1 \mathrm{ab}$ & 80.3 & $11.3 \mathrm{~b}$ \\
46 & $79 \mathrm{~b}$ & $60 \mathrm{~b}$ & $139 \mathrm{~b}$ & $45.9 \mathrm{a}$ & 80.4 & $11.9 \mathrm{~b}$ \\
69 & $97 \mathrm{a}$ & $71 \mathrm{a}$ & $168 \mathrm{a}$ & $45.9 \mathrm{a}$ & 80.3 & $13 \mathrm{a}$ \\
Mean & 75.3 & 53.5 & 128.8 & 45.4 & 80.2 & 11.9 \\
\hline LSD (P $\leq .05)$ & 8.6 & 7.6 & 14 & 1.07 & NS & 0.71 \\
\hline Cultivars & & & & & & \\
\hline Ude & $81 \mathrm{abc}$ & $54 \mathrm{bc}$ & $134 \mathrm{ab}$ & $49.5 \mathrm{a}$ & $80.7 \mathrm{a}$ & $13.4 \mathrm{a}$ \\
CDSS93Y107 & $70 \mathrm{cde}$ & $45 \mathrm{~cd}$ & $114 \mathrm{~cd}$ & $43.6 \mathrm{bc}$ & $81.6 \mathrm{a}$ & $10.6 \mathrm{bc}$ \\
Ejersa & $82 \mathrm{ab}$ & $51 \mathrm{bcd}$ & $133 \mathrm{abc}$ & $44.4 \mathrm{~b}$ & $81.3 \mathrm{a}$ & $13.4 \mathrm{a}$ \\
Bekelcha & $88 \mathrm{a}$ & $57 \mathrm{~b}$ & $144 \mathrm{a}$ & $48.8 \mathrm{a}$ & $81.1 \mathrm{a}$ & $13.4 \mathrm{a}$ \\
CD94523 & $75 \mathrm{bcd}$ & $47 \mathrm{~cd}$ & $122 \mathrm{bcd}$ & $42.5 \mathrm{c}$ & $79.7 \mathrm{~b}$ & $10.8 \mathrm{bc}$ \\
Cocorit 71 & $69 \mathrm{de}$ & $43 \mathrm{~d}$ & $112 \mathrm{~d}$ & $43.8 \mathrm{bc}$ & $78.7 \mathrm{bc}$ & $11.4 \mathrm{~b}$ \\
Inglize & $64 \mathrm{e}$ & $80 \mathrm{a}$ & $143 \mathrm{a}$ & $44.9 \mathrm{~b}$ & $78.5 \mathrm{c}$ & $10.2 \mathrm{c}$ \\
Mean & 75.6 & 53.9 & 128.9 & 45.4 & 80.2 & 11.9 \\
\hline LSD (P $\leq .05)$ & 11 & 10 & 19 & 1.42 & 0.96 & 0.94 \\
\hline CV (\%) & 18 & 22.9 & 18 & 3.8 & 1.5 & 9.7 \\
\hline
\end{tabular}

Means followed by the same letter in a column and row are not significantly different at $5 \%$ level of significance, $\mathrm{GNU}=$ grain $\mathrm{N}$ uptake, SNU= straw $\mathrm{N}$ uptake, TNU= Total $\mathrm{N}$ uptake, TKW= thousand kernel weight,

HLW= hectoliter weight, GPC= grain protein content 


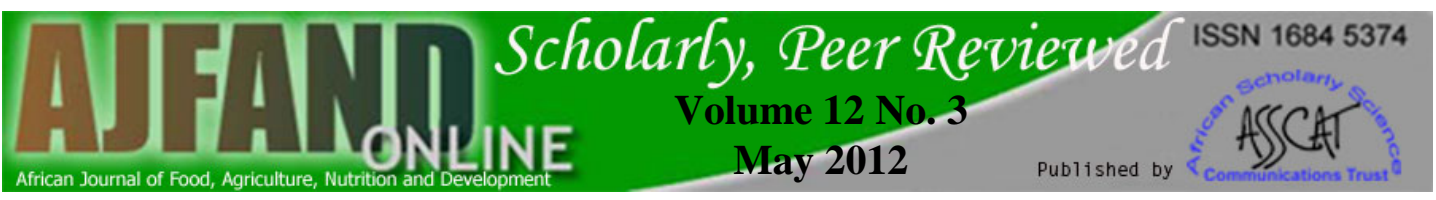

Table 4: The interaction effect of nitrogen rates and cultivars on grain yield of durum wheat (mean values)

\begin{tabular}{|c|c|c|c|c|c|}
\hline \multirow[t]{2}{*}{ Cultivars } & \multicolumn{4}{|c|}{ Nitrogen rates $\left(\mathrm{kg} \mathrm{N} \mathrm{ha}^{-1}\right)$} & \multirow[b]{2}{*}{ Mean } \\
\hline & 0 & 23 & 46 & 69 & \\
\hline Ude & $2604 \mathrm{ij}$ & 3341d-h & 4014bcd & 3996bcd & 3489 \\
\hline CDSS93Y107 & 2900g-j & 3193f-i & 4110bc & 4923a & 3782 \\
\hline Ejersa & $2313 j$ & 3698c-f & 3913b-e & 3911b-e & 3459 \\
\hline Bekelcha & 3371d-h & 3498c-g & 3437c-h & $4605 \mathrm{ab}$ & 3728 \\
\hline CD94523 & 3740c-f & 3408c-h & $3805 c-f$ & 4989a & 3986 \\
\hline Cocorit 71 & 2785hij & 3560c-g & 3813c-f & 3934bcd & 3523 \\
\hline Inglize & 3206e-i & 3471c-h & 3842c-f & 3960bcd & 3620 \\
\hline Mean & 2988 & 3453 & 3848 & 4331 & \\
\hline $\operatorname{LSD}(\mathrm{P} \leq .05)$ & $\mathrm{N}=269.3$ & $C=356.3$ & $\mathrm{~N} \times \mathrm{C}=712.5$ & & \\
\hline CV (\%) & & 11.9 & & & \\
\hline
\end{tabular}

Means followed by the same letter in a column and row are not significantly different at $5 \%$ level of significance, $\mathrm{N}=$ nitrogen, $\mathrm{C}=$ cultivar 


\section{REFERENCES}

1. Gebre-Mariam $\mathbf{H}$ Wheat Production and Research in Ethiopia. In: Gebremariam H, DG Tanner \& M Hulluka (Eds). Wheat Research in Ethiopia: A Historical Perspective. IAR/CIMMYT, Addis Ababa, Ethiopia, 1991; 1-15.

2. Woldeab A, Mamo T, Bekele $\mathbf{M}$ and T Ajema Soil Fertility Management Studies on Wheat in Ethiopia. In: Gebre-mariam H, DG Tanner \& M Hulluka (Eds). Wheat Research in Ethiopia: A Historical Perspective. IAR/CIMMYT, Addis Ababa, Ethiopia, 1991; 137-172.

3. CSA (Central Statistical Agency). Agricultural sample survey 2009/10. Report on area production of crops (private Peasant holdings, Meher season). Stat. Bullet. 466, Addis Ababa, 2010.

4. Peña RJ, Trethowan R, Pfeiffer WH and M van Ginkel Quality (End-use) Improvement in Wheat: Compositional, Genetic, and Environmental Factors. In: Basra AS and LS Randhawa (Eds). Quality Improvement in Field Crops, Food Products Press, Binghampton, NY, 2002; 1-39.

5. Tesemma T Durum Wheat Breeding in Ethiopia. In: M van Ginkel and DG Tanner (Eds). Fifth Regional Wheat Workshop for Eastern, Central and Southern Africa and Indian Ocean, Mexico, DF, CIMMYT, 1987; 18-22.

6. Alam MS, Nesa MN, Khan SK, Hossain MB and A Hoque Varietal differences on yield and yield contributing characters of wheat under different levels of nitrogen and planting methods. J. Appl. Sci. Res. 2007; 3(11): 13881392.

7. Gooding MJ and WP Davies Wheat Production and Utilization: Systems, Quality and the Environment. CAB International, UK. 1997; 355p.

8. Bushuk W Wheat breeding for end product use. Euphytica. 1998; 100: 137145.

9. Ames NP, Clarke JM, Dexter JE, Woods SM, Selles F and B Marchylo Effect of nitrogen fertilizer on protein quality and gluten strength parameters in durum wheat (Triticum turgidum L. var. durum) cultivars of variable gluten strength. Cereal Chem. 2003; 80: 203-211.

10. Gelalcha S, Debelo D, Girma B, Payne TS, Alemayehu Z and B Yaie Milling and Baking Quality of Ethiopían Bread Wheat Cultivars. Proceedings of the $11^{\text {th }}$ Regional Wheat Workshop for Eastern, Central and Southern Africa. CIMMYT, Addis Ababa, Ethiopia, 2000; 87-96.

11. Khattari S Response of two durum wheat varieties to different rates and sources of nitrogen in Jordan. Dirasat, 1984; 11: 79-85. 
12. Bechere E, Peña RJ and $\mathbf{D}$ Mitiku Glutenin composition, quality characteristics and agronomic attributes of durum wheat cultivars released in Ethiopia. African Crop Sci. J. 2002; 10 (2): 173-182.

13. Dewis $\mathbf{J}$ and $\mathbf{P}$ Freitas Physical and chemical methods of soil and analysis. FAO Bullet. No.10. Rome. 1970; 175p.

14. Jackson ML Soil Chemical Analysis. Prentice Hall Inc., Engle wood cliffs, New Jersey, 1958.

15. Page AL Methods of Soil Analysis. Part2. Chemical and Microbiological Properties, Madison Wisconsin. 1982.

16. Chapman HD Cation Exchange Capacity by Ammonium Saturation. In: Black CA, Ensminger LE and FE Clark (Eds). Method of Soil Analysis. American Society of Agronomy. Madison Wisconsin, USA. 1965; 891-901.

17. Olsen SR, Cole CW, Watanabe FS and LA Dean Estimation of Available Phosphorus in Soils by Extraction with Sodium Bicarbonate Circular 939, US. Department of Agriculture.1954.

18. AACC. Approved Methods of the American Association Cereal Chemists. American Association of Cereal Chemists, Inc., St. Paul, Minnesota. 2000

19. Fischer RA Irrigated spring wheat and timing and amount of nitrogen fertilizer: II. Physiology of grain yield response. Field Crops Res.1993; 33: 57-80.

20. SAS (Statistical Analysis System). SAS Institute, Cary, NC, USA.

21. Khan MA, Hussain I and MS Baloch Wheat yield potential current status and future strategies. Pakistan J Biol. Sci, 2000; 3: 82-86.

22. Hassan MA, Kamal AMA and MR Islam A study on the management system of organic and inorganic fertilizers on the yield and yield components in wheat (Triticum asetivum L). Thailand J Agri. Sci. 1998; 31: 196-201.

23. Gorfu A, Taa A, Tanner DG and $\mathbf{W}$ Mwangi On farm research derive fertilizer recommendations for small scale bread wheat production: Methodological issues and technical results. Research Report No. 14. IAR, Addis Ababa, Ethiopia, 1991; 37p.

24. Tarekegne A, Tanner DG, Tessema T and C Mandefro Agronomic and economic evaluation of the on farm $\mathrm{N}$ and $\mathrm{P}$ response of bread wheat grown on two contrasting soil types in Central Ethiopia. Proceedings of the $11^{\text {th }}$ Regional Wheat Workshop for Eastern, Central and Southern Africa. CIMMYT, Addis Ababa, Ethiopia, 239-252. 
25. Campbell CA, Zenter RP, Selles F and BG McConkey Available water and nitrogen effects on yield components and grain nitrogen of zero-till spring wheat. Agron. J. 1993; 85: 114-120.

26. Dhugga KS and JG Waines Analysis of nitrogen accumulation and use in bread and durum wheat. Crop Sci. 1989; 29: 1232-1239.

27. Makowska A, Obuchowski W, Sulewska H, Koziara W and $H$ Paschke Effect of nitrogen fertilization of durum wheat varieties on some characteristics important for pasta production. Techn. Aliment. 2008; 7(1): 2939.

28. Sissions M Pasta. In: Wrigley C, Corke H and CE Walker (Eds) Encyclopedia of Grain Science. Vol.2. Elsevier Academic Press, Amsterdam. 2004; 363-375

29. Kirrilov YAI and VD Pavlov Effect of fertilizer on yield and protein contents in wheat grain. Agrochim. 1989; 1: 49-51.

30. Bechere E, Kebede $\mathbf{H}$ and $\mathbf{G}$ Belay Durum Wheat in Ethiopia: An Old Crop in an Ancient land. Institute of Biodiversity Conservation and Research. Addis Ababa, Ethiopia. 2000; 68p.

31. Zadocks JC, Chang TT and CF Kanzak A decimal code for the growth of stage of cereals. Weed Res. 1974; 14: 415-421.

32. Gashawbeza B, Assefa S, Yaekob A, Zemede A, Kifetew J and B Mekuria Effect of nitrogen fertilizer levels and varieties on gluten content and some rheological characteristics of durum wheat flour. In: Kinyua MG, J Kamwaga, JO Owuoche, AC Ndiema, PN Njau, DK Friesen \& D Ouya (Edn). Proceedings of the 12th Regional Wheat Workshop for Eastern, Central, and Southern Africa. Nakuru, Kenya, 22-26 November 2004. Mexico, D.F.; CIMMYT and KARI, 2006; 2-8. 